\title{
PENGARUH FUNGSI KEPEMIMPINAN, MOTIVASI DAN \\ DISIPLIN KERJA TERHADAP KINERJA KARYAWAN \\ DI PT MITRAMETAL PERKASA KARAWANG
}

\author{
Matius Teguh Widagdo \\ Universitas Singaperbangsa Karawang \\ mrteguh31@gmail.com
}

\begin{abstract}
ABSTRAK
Penelitian ini dilakukan dengan tujuan untuk meneliti dan membuktikan fenomena yang ada di PT. Mitrametal Perkasa dengan menganalisis seberapa besar pengaruh fungsi kepemimpinan, motivasi dan disiplin kerja terhadap kinerja karyawan.

Metode analisis yang digunakan adalah deskriptif dan verifikatif. Alat analisis menggunakan rentang skala dan analisis jalur dimana dalam proses perhitungan korelasi dan regresi antar variabel baik secara parsial maupun simultan digunakan SPSS.

Berdasarkan hasil penelitian mengenai Pengaruh Fungsi Kepemimpinan, MotivasI dan Disiplin Kerja terhadap Kinerja Karyawan di PT. Mitrametal Perkasa, dapat diambil kesimpulan bahwa secara keseluruhan gambaran variabel penelitian berdasarkan persepsi responden menunjukan bahwa Fungsi Kepemimpinan, Disiplin Kerja dan Kinerja Karyawan berada pada kategori cukup baik, sedangkan total pengaruh secara simultan Kepemimpinan, Motivasi, dan Disiplin Kerja berpengaruh terhadap Kinerja Karyawan di PT. Mitrametal Perkasa sebesar 65,9\% Sedangkan faktor lain yang tidak diteliti dan turut mempengaruhi kinerja ditunjukkan oleh nilai Pye= 0.341 atau sebesar 34,1\%. Variabel lain dimaksud seperti lingkungan kerja, kompensasi, budaya organisasi, komunikasi dan lain sebagainya.
\end{abstract}

Kata Kunci : Fungsi Kepemimpinan, Motivasi Kerja, Disiplin Kerja dan Kinerja Karyawan 


\section{PENDAHULUAN}

Industri komponen otomotif di Indonesia baik untuk mobil dan sepeda motor adalah salah satu rantai nilai industri yang berkembang sangat pesat, bernilai paling tinggi dan paling menjanjikan. Hal ini dikarenakan dengan semakin membanjirnya produk unit kendaraan roda dua di pasaran maka pada akhirnya permintaan untuk komponen khususnya komponen habis pakai pun semakin meningkat. Kondisi seperti ini membuka peluang usaha pembuatan komponen pun menjadi bertumbuh sehingga banyak pilihan jenis dan harga produk yang tersedia di pasar.

Dalam upaya memenangkan persaingan di pasar terutama pada perusahaan penyedia komponen otomotif untuk purna jual, setiap perusahaan dituntut untuk mampu menghasilkan produk baik barang maupun jasa yang berdaya saing tinggi, yaitu produk yang memiliki keunggulan-keunggulan tertentu di mana tentunya akan sangat tergantung dari kualitas sumber daya manusianya. Kondisi ini bisa dapat dilihat dari hasil kerja atau kinerja yang ditunjukkan oleh karyawan atau organisasi yang bersangkutan dalam menyelesaikan tugas yang menjadi tanggung jawabnya.

Berkaitan dengan kinerja yang sangat utama dalam membawa kemajuan suatu perusahaan, gambaran atas kinerja di PT. Mitrametal Perkasa sebagai salah satu perusahaan manufaktur komponen otomotif yang menyediakan komponen purna jual juga, tampak seperti tabel prasurvey yang dilakukan terhadap 30 responden berikut ini :

Tabel 1

Prasurvey Kinerja Karyawan

PT.Mitrametal Perkasa

\begin{tabular}{|l|c|l|}
\hline \multicolumn{1}{|c|}{ Dimensi } & $\begin{array}{l}\text { Rekapitulasi Rata-Rata } \\
\text { Jawaban Responden }\end{array}$ & $\begin{array}{l}\text { Kriteria } \\
\text { Jawaban }\end{array}$ \\
\hline 1. Dapat Diandalkan & 2,923 & Cukup Baik \\
\hline 2. Penyesuaian Irama Kerja & 3,042 & Cukup Baik \\
\hline 3. Prakarsa & 3,226 & Cukup Baik \\
\hline 4. Kerjasama & 3,425 & Baik \\
\hline 5. Kepemimpinan & 3,129 & Cukup Baik \\
\hline 6. Perencanaan Kerja dan Organisasi & 3,042 & Cukup Baik \\
\hline 7. Pengendalian & 3,323 & Cukup Baik \\
\hline
\end{tabular}

Sumber : Hasil Prasurvey 2017, diolah peneliti 
Dari hasil survey didapatkan bahwa rata-rata kinerja karyawan ada dalam kategori cukup baik bukan pada baik. Artinya angka ini menunjukkan bahwa kinerja karyawan ternyata masih jauh dari yang diharapkan.

\section{METODE PENELITIAN}

\section{Paradigma Penelitian}

Dalam penelitian ini terdapat empat variabel yaitu fungsi kepemimpinan (X1), motivasi (X2), disiplin kerja (X3) dan kinerja (Y) yang dibangun sehingga menjadi paradigma seperti gambar di bawah ini :

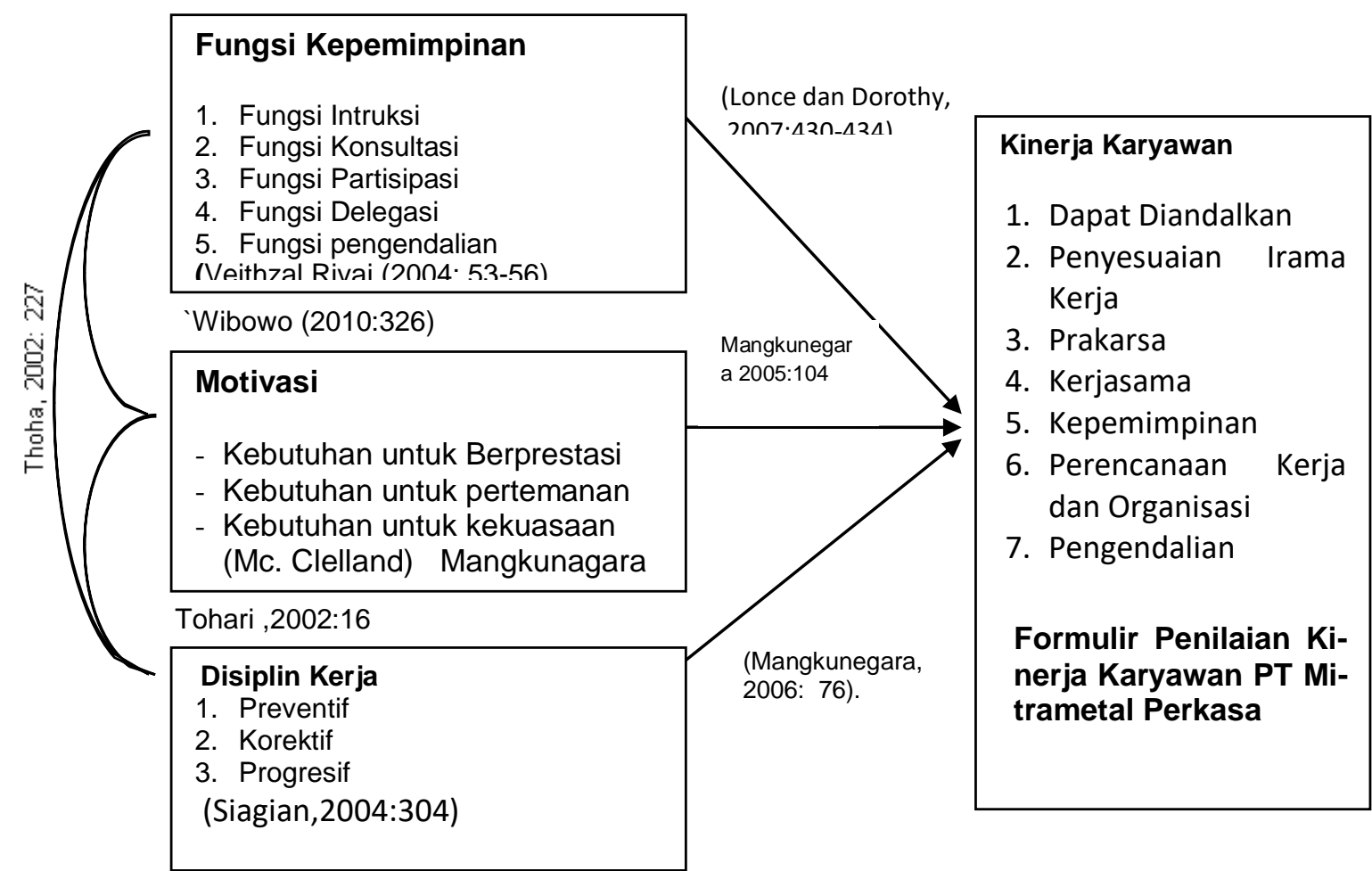

Gambar 1

Paradigma Penelitian

2. Populasi dan sampel

Sugiono (2002, h 72-73) mendefinisikan populasi sebagai wilayah generalisasi yang terdiri dari obyek-obyek yang mempunyai kualitas dan karakteristik tertentu yang ditetapkan oleh peneliti untuk dipelajari dan kemudian ditarik kesimpulan. Lebih lanjut dijelaskan bahwa sampel merupakan bagian dari jumlah dan karakteristik yang 
dimiliki oleh populasi tersebut. Untuk kepentingan penarikan sampel dari sebuah populasi Suharsini Arikunto $(2003,107)$ berpendapat apabila populasi kurang dari 100 orang, lebih baik diambil semua populasi untuk dijadikan sampel sehingga penelitiannya merupakan penelitian populasi. Selanjutnya jika populasinya besar diatas 100 orang maka diambil $10-15 \%$ atau lebih dari itu.

Berdasarkan pemahaman tentang konsep populasi dan sampel diatas, maka yang menjadi populasi dalam penelitian ini adalah seluruh karyawan pada PT. Mitrametal Perkasa Karawang. Mengingat anggota populasinya berjumlah 60 orang, maka penelitian ini dilakukan terhadap populasi.

\section{Pengumpulan Data}

Teknik pengumpulan data yang digunakan dalam penelitian ini terdiri dari kuesioner, wawancara, dan studi dokumenter. Kuesioner dimaksudkan untuk menjaring data tentang fungsi kepemimpinan, motivasi kerja, disiplin kerja dan kinerja karyawan. Sementara wawancara dimaksudkan untuk menjaring data ketiga variabel penelitian yang tidak dapat dijaring dengan teknik kuesioner.

Dalam penyusunan instrumen digunakan model dari Rensis Likert yakni dengan option Sangat setuju (SS), Setuju (S), Cukup Setuju (CS), tidak setuju (KS) dan Sangat tidak Setuju (TS). Masing-masing option diberikan bobot mulai dari 5 untuk sangat setuju hingga bobot 1 untuk option sangat tidak setuju.

\section{Rancangan Analisis dan Uji Hipotesis}

a. Analisis Korelasi

Untuk menguji korelasi antara variabel penelitian digunakan teknik analisa korelasi. Adapun analisis korelasi dimaksudkan untuk menguji korelasi kepemimpinan, motivasi, disiplin kerja dan kinerja. Adapun rumus yang digunakan adalah sebagai berikut :

$$
\mathrm{r}=\frac{n\left(\sum X Y\right)-\left(\sum X\right)\left(\sum Y\right)}{\sqrt{n \sum X^{2}-\left(\sum X\right)^{2} \sqrt{n \sum Y^{2}-\left(\sum Y\right)^{2}}}}
$$

$$
\begin{array}{cll}
\text { Dimana : } & \mathrm{r} & =\text { Koefisien korelasi } \\
\mathrm{N} & =\text { jumlah sampel } \\
\mathrm{X} & =\text { variabel independen (bebas) } \\
\mathrm{Y} & =\text { Variabel dependen (terikat) } \\
& \text { Sumber }: \text { Sugiyono (2007:212) }
\end{array}
$$




\section{b. Analisis Jalur}

Untuk melihat pengaruh secara parsial maupun simultan dari pengaruh fungsi kepemimpinan terhadap disiplin dan motivasi serta implikasinya pada kinerja karyawan digunakan Analisis Jalur (Path Analysis).

Adapun diagram jalur sebagaimana dimaksud tampak di bawah ini :

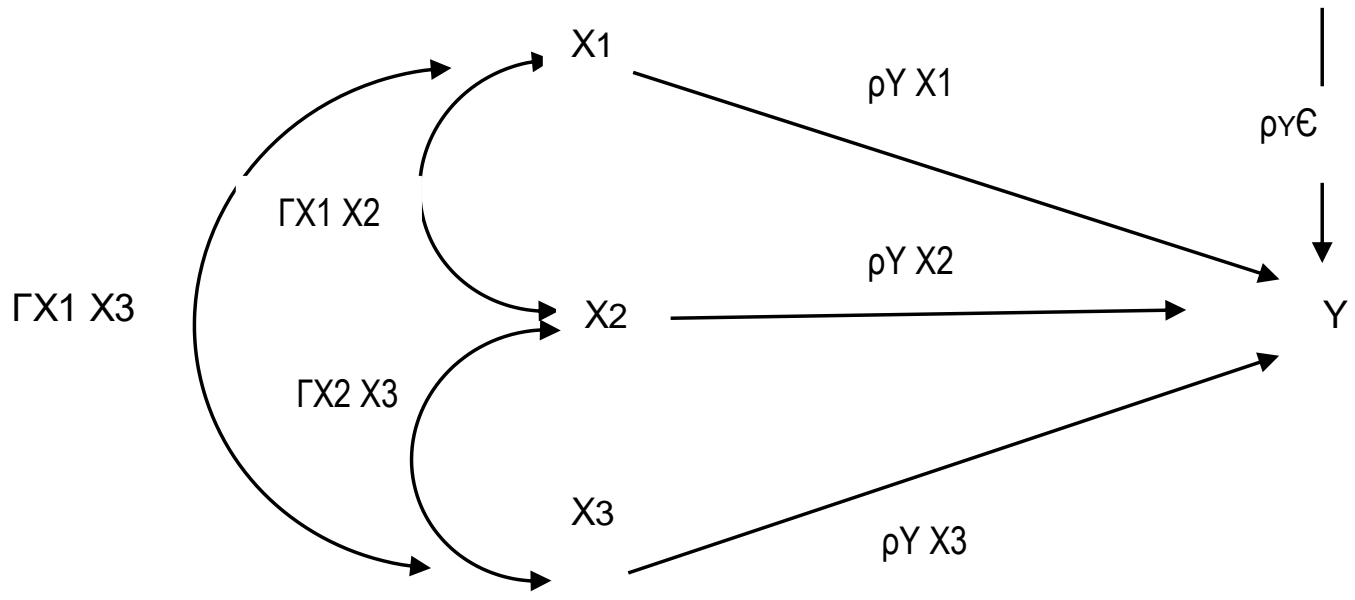

Gambar 2

Diagram jalur

c. Uji Hipotesa

Dalam penelitian ini yang akan dikaji adalah berapa besar pengaruh Fungsi Kepemimpinan (X1), Motivasi Kerja (X) dan Disiplin Kerja (X3) terhadap Kinerja Karyawan (Y).

Pengujian hipotesis dilakukan dengan dua tahap yaitu :

1. Pengujian secara parsial

Pada pengujian hipotesis parsial digunakan uji t dengan kriteria uji, Ho ditolak jika nilai hitung $\geq \mathrm{t}$ tabel, dengan demikian $\mathrm{H} 1$ diterima.

2. Pengujian secara simultan atau keseluruhan (Over all)

Pengujian hipotesis secara bersama-sama dilakukan dengan menggunakan Uji F yaitu pengaruh Fungsi Kepemimpinan, Motivasi Kerja dan Disiplin Kerja terhadap Kinerja Karyawan dengan kriteria

Pada pengujian secara simultan ini digunakan kriteria uji Ho ditolak jika $F$ hitung > F tabel dengan $\alpha=5 \%$ 


\section{PEMBAHASAN HASIL PENELITIAN}

1. Deskripsi Variabel Penelitian

Dari hasil pengolahan data kuesioner didapatkan gambaran variabel peneltitian sebagai berikut :

Tabel 2

Rekapitulasi Variabel Penelitian

\begin{tabular}{|c|c|c|c|c|}
\hline \multicolumn{1}{|c|}{ Variabel } & $\begin{array}{c}\text { Pernyataan } \\
\text { Kuesioner }\end{array}$ & $\begin{array}{c}\text { Total skor } \\
\text { rata-rata }\end{array}$ & Mean & Kriteria \\
\hline $\begin{array}{c}\text { Fungsi Kepemimpinan } \\
\text { (X1) }\end{array}$ & 16 & 192,4 & 3,23 & Cukup Baik \\
\hline $\begin{array}{c}\text { Motivasi Kerja } \\
\text { (X2) }\end{array}$ & 15 & 182,4 & 3,04 & Cukup Baik \\
\hline $\begin{array}{c}\text { Disiplin Kerja } \\
\text { (X3) }\end{array}$ & 15 & 203,4 & 3,39 & Cukup Baik \\
\hline $\begin{array}{l}\text { Kinerja } \\
\text { (Y) }\end{array}$ & 19 & 193,4 & 3,21 & Cukup Baik \\
\hline
\end{tabular}

Berdasar tabel 2 di atas terlihat bahwa empat variabel yang dilakukan penelitian ternyata mempunyai kriteria cukup baik. Artinya masih jauh dari kondisi baik. Jika dari total skor rata-rata yang terdapat pada tabel di atas dilihat dengan menggunakan rentang skala, maka didapatkan hal sebagaimana gambar di bawah ini.

(Y)

193,5

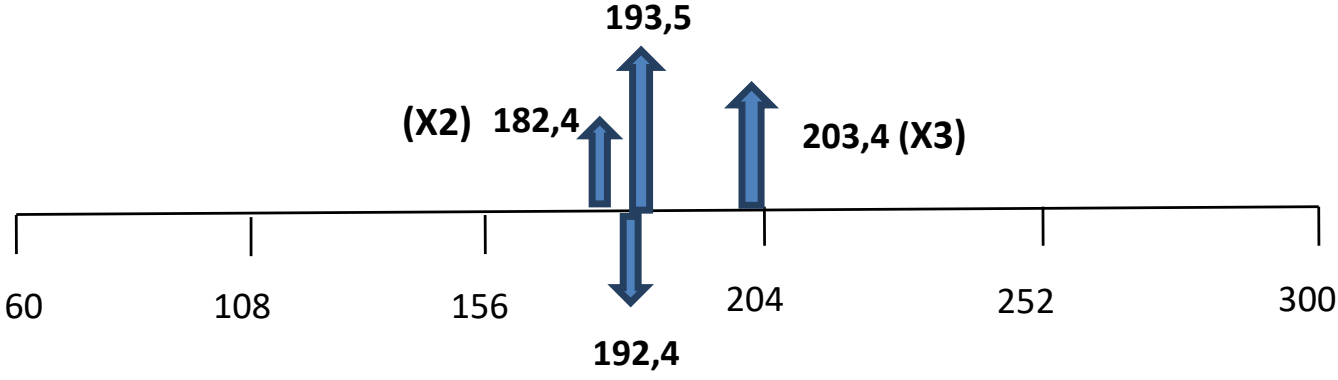

(X1)

Gambar 3

Rentang Skala Variabel X1, X2, X3 dan Y

2. Analisisa Korelasi 
Perhitungan koefisien korelasi menggunakan analisis korelasi Pearson Product Moment, dilakukan guna mengetahui seberapa kuat hubungan antara beberapa variabel independen yang diteliti. Perhitungan koefisien korelasi menggunakan program SPSS, dengan hasil seperti yang tertera pada tabel 3 di di bawah ini :

Tabel 3

Koefisien Korelasi Antar Variabel

\begin{tabular}{|ll|r|r|r|}
\hline & & Kepemimpinan & Motivasi & Disiplin \\
\hline Kepemimpinan & Pearson Correlation & 1 &, 150 &, 139 \\
& Sig. (2-tailed) & &, 254 &, 289 \\
& $\mathrm{~N}$ & 60 & 60 & 60 \\
\hline Motivasi & Pearson Correlation &, 150 & 1 &, 075 \\
& Sig. (2-tailed) &, 254 & &, 571 \\
& $\mathrm{~N}$ & 60 & 60 & 60 \\
& Pearson Correlation &, 139 &, 075 & 1 \\
& Sig. (2-tailed) &, 289 &, 571 & \\
& $\mathrm{~N}$ & 60 & 60 & 60 \\
\hline
\end{tabular}

Sumber : Data Hasil pengolahan melalui Sofware SPSS

Berdasarkan tabel 3 terlihat maka ternyata ada hubungan yang positif antara variabel bebas dalam penelitian. Untuk jelasnya besarnya hubungan (koefisien korelasi) tersebut adalah sebagaimana ditunjukkan gambar 4 berikut.

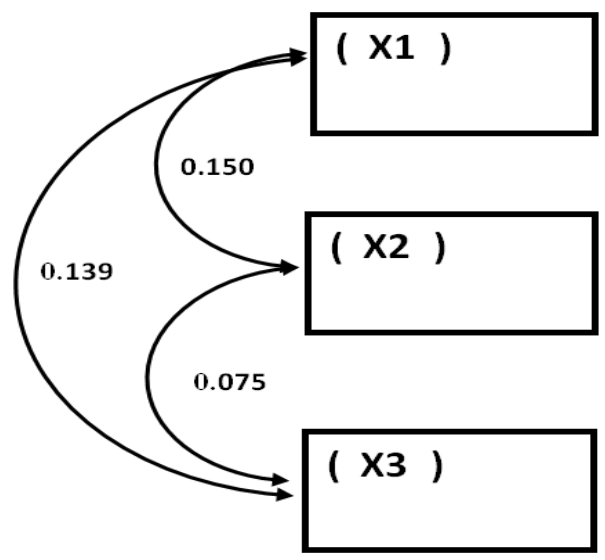

Gambar 4

Hubungan antara variabel Fungsi Kepemimpinan, Motivasi dan Disiplin Kerja 
Dengan mengacu pada tabel di bawah ini, maka dapat dijelaskan kriteria keeratan hubungan antar variabel dependen sebagai berikut :

Tabel 4

Kriteria penafsiran tingkat hubungan antar variabel

\begin{tabular}{|l|l|}
\hline Koefisien Korelasi & Tingkat Hubungan \\
\hline $0,00-0,199$ & Sangat rendah \\
\hline $0,20-0,399$ & Rendah \\
\hline $0,40-0,599$ & Sedang \\
\hline $0,60-0,799$ & Kuat \\
\hline $0,80-1,000$ & Sangat Kuat \\
\hline
\end{tabular}

Sumber : Sugiyono (2009: 257)

a. Besar hubungan antara variabel Fungsi Kepemimpinan $\left(\mathrm{X}_{1}\right)$ dengan Motivasi Kerja $\left(\mathrm{X}_{2}\right)$ adalah $\mathbf{0 . 1 5 0}$ atau sangat rendah dan searah karena nilainya positif. Angka ini menyatakan bahwa jika Kepemimpinan $\left(\mathrm{X}_{1}\right)$ naik sebesar satu satuan, maka diikuti dengan kenaikan besaran Motivasi Kerja $\left(X_{2}\right)$ sebesar $\mathbf{0 . 1 5 0}$ satuan.

b. Besar hubungan antara variabel Kepemimpinan $\left(\mathrm{X}_{1}\right)$ dengan Disiplin Kerja $\left(\mathrm{X}_{3}\right)$ bernilai 0.139 yang dapat diinterpretasikan sangat rendah dan searah karena nilainya positif. Dengan angka ini dapat diartikan apabila Kepemimpinan $\left(\mathrm{X}_{1}\right)$ naik sebesar satu satuan, maka di ikuti oleh kenaikan Disiplin Kerja $\left(\mathrm{X}_{3}\right)$ sebesar 0.139 satuan.

c. Demikian pula dengan hubungan antara variabel Motivasi Kerja $\left(\mathrm{X}_{2}\right)$ dengan Disiplin Kerja $\left(\mathrm{X}_{3}\right)$ didapatkan nilai sebesar $\mathbf{0 . 0 7 5}$ atau adanya tingkat hubungan yang Sangat Rendah dan searah karena nilainya. Pernyataan di atas dapat diartikan apabila besaran Motivasi Kerja $\left(\mathrm{X}_{2}\right)$ naik satu satuan, maka akan diikuti oleh kenaikan besaran Disiplin Kerja $\left(\mathrm{X}_{3}\right)$ sebesar 0.075 satuan.

3. Analisa Jalur

Berdasarkan hasil perhitungan dengan menggunakan program SPSS diperoleh besaran koefisien jalur seperti yang dijelaskan pada tabel 5 berikut ini : 
Tabel 5

Nilai Koefisien Jalur

\begin{tabular}{|c|c|c|c|c|c|c|}
\hline \multirow{2}{*}{\multicolumn{2}{|c|}{ Model }} & \multicolumn{2}{|c|}{ Unstandardized Coefficients } & \multirow{2}{*}{$\begin{array}{c}\text { Standardized } \\
\text { Coefficients } \\
\text { Beta }\end{array}$} & \multirow[b]{2}{*}{$\mathrm{T}$} & \multirow[b]{2}{*}{ Sig. } \\
\hline & & B & Std. Error & & & \\
\hline \multirow[t]{4}{*}{1} & (Constant) & $-9,449$ & 5,023 & & $-1,881$ &, 065 \\
\hline & Kepemimpinan & ,293 &, 056 & ,416 & 5,224 &, 000 \\
\hline & Motivasi & ,326 &, 058 & ,447 & 5,660 &, 000 \\
\hline & Disiplin & ,323 & ,064 & ,397 & 5,026 & ,000 \\
\hline
\end{tabular}

a. Dependent Variable: Kinerja Karyawan

Berdasarkan tabel 5 di atas diperoleh besaran koefisien jalur antar variabel penelitian yang dapat di lihat pada tabel 6 sebagai berikut :

Tabel 6

Hasil Perhitungan Jalur

\begin{tabular}{|c|c|}
\hline Variabel & Koefisien Jalur \\
\hline Kepemimpinan $\left(\mathrm{X}_{1}\right)$ & 0.416 \\
\hline Motivasi Kerja $\left(\mathrm{X}_{2}\right)$ & 0.447 \\
\hline Disiplin Kerja $\left(\mathrm{X}_{3}\right)$ & 0.397 \\
\hline
\end{tabular}

Sumber : Hasil perhitungan statistik

Dari tabel 6 menggambarkan hasil perhitungan jalur, bahwa variabel $\mathrm{X}_{1}$ mempunyai koefisien jalur sebesar 0.416, Variabel $\mathrm{X}_{2}$ mempunyai koefisien jalur sebesar 0.447 dan Variabel $\mathrm{X}_{3}$ mempunyai koefisien jalur sebesar 0.397. Berdasarkan atas hasil analisis jalur variabel Kepemimpinan, Motivasi Kerja dan Disiplin Kerja terhadap Kinerja Karyawan maka dapat dapat dijelaskan pengaruh variabel seperti pada gambar 6 berikut ini : 


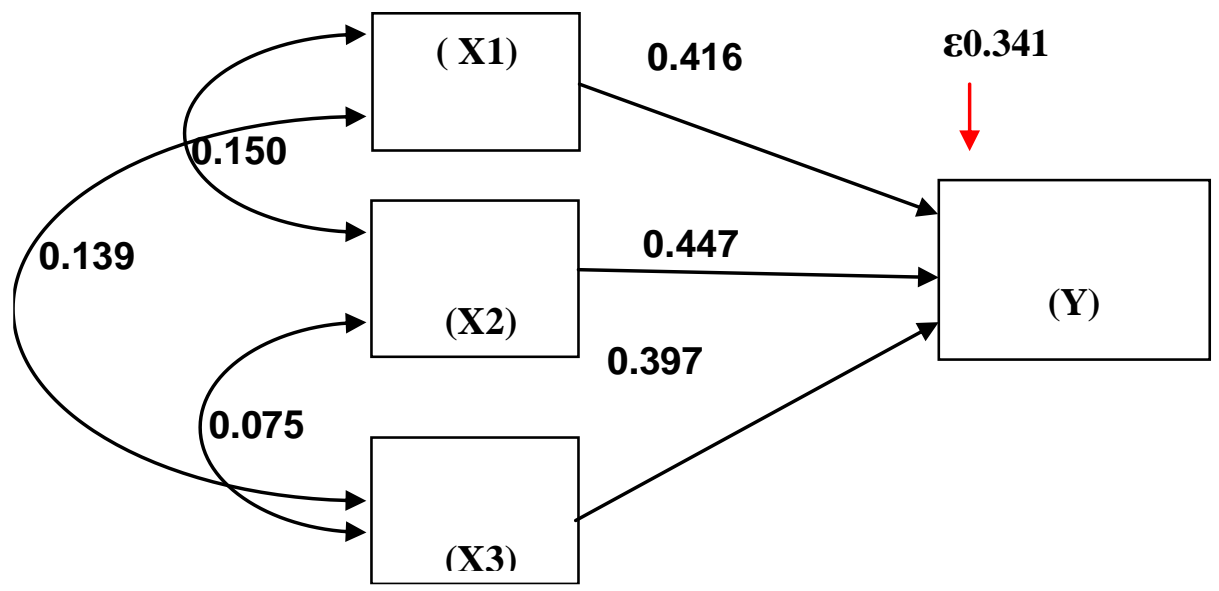

Gambar 6

Pengaruh Fungsi Kepemimpinan, Motivasi Kerja dan Disiplin Kerja Terhadap Kinerja

Selanjutnya dari gambar 6, dapat diperoleh persamaan jalur sebagai berikut :

$$
Y=0.416 X_{1}+0.447 X_{2}+0.397 X_{3}+G
$$

$$
\begin{aligned}
\text { Dimana } Y & =\text { Kinerja Karyawan } \\
X_{1} & =\text { Kepemimpinan } \\
X_{2} & =\text { Motivasi Kerja } \\
X_{3} & =\text { Disiplin Kerja }
\end{aligned}
$$

Sedangkan besarnya pengaruh dari masing-masing variabel bebas terhadap variabel terikat baik pengaruh langsung (Direct Effect) maupun pengaruh tidak langsung (Indirect Effect) dapat di lihat pada tabel berikut ini :

Tabel 7

Pengaruh langsung dan pengaruh tidak langsung Variabel bebas terhadap variabel terikat

\begin{tabular}{|l|c|c|c|c|c|c|}
\hline \multirow{2}{*}{ Variabel } & \multirow{2}{*}{$\begin{array}{l}\text { Pengaruh } \\
\text { Langsung }\end{array}$} & \multicolumn{4}{|c|}{ Pengaruh Tidak Langsung } & \multirow{2}{*}{$\begin{array}{c}\text { Total } \\
\text { Pengaruh }\end{array}$} \\
\cline { 3 - 6 } & & $\mathbf{X}_{\mathbf{1}}$ & $\mathbf{X}_{\mathbf{2}}$ & $\mathbf{X}_{\mathbf{3}}$ & Total & \\
\hline Kepemimpinan & $17,31 \%$ & & $2,79 \%$ & $2,30 \%$ & $5,08 \%$ & $22,39 \%$ \\
\hline Motivasi Kerja & $19,98 \%$ & $2,79 \%$ & & $1,33 \%$ & $4,12 \%$ & $24,10 \%$ \\
\hline Disiplin Kerja & $15,76 \%$ & $2,30 \%$ & $1,33 \%$ & & $3,63 \%$ & $19,39 \%$ \\
\hline \multicolumn{7}{|c|}{$T 0 t a l$ Pengaruh X Ke Y } \\
\hline
\end{tabular}

Sumber : Hasil perhitungan 
Hasil perhitungan Koefisien determinasi ( $\mathrm{R}$ kuadrat) yang dinyatakan dalam persentase mengambarkan besarnya kontribusi semua variabel bebas yaitu Fungsi Kepemimpinan, Motivasi Kerja dan Disiplin Kerja dalam menentukan variasi Kinerja Karyawan adalah sebesar $\mathbf{6 5 , 9 \% . ~}$

Sedangkan faktor lain yang tidak diteliti dan turut mempengaruhi Kinerja Karyawan pada PT. Mitrametal Perkasa ditunjukkan oleh nilai PyC $=0.341$ atau sebesar $34,1 \%$..

\section{KESIMPULAN}

Berdasarkan tujuan penelitian yang selanjutnya dibandingkan dengan hasil penelitian maka dapat dibuat kesimpulan sebagai berikut :

1. Fungsi Kepemimpinan, motivasi kerja, disiplin kerja dan kinerja karyawan di PT. Mitrametal Perkasa secara keseluruhan dalam kategori cukup baik rata-rata total skor berada di rentang skala $156-204$.

2. Secara parsial disimpulkan bahwa :

a. Fungsi kepemimpinan mempunyai pengaruh cukup dominan terhadap kinerja dengan nilai sebesar $22,3 \%$.

b. Motivasi kerja memberikan pengaruh dominan terhadap kinerja sebesar $24,1 \%$

c. Kontribusi terendah diberikan variabel disiplin kerja dengan hanya memberikan pengaruh sebesar 19,3\% terhadap kinerja.

3. Secara simultan Fungsi Kepemimpinan, Motivasi Kerja, dan Disiplin Kerja berpengaruh terhadap Kinerja Karyawan di PT. Mitrametal Perkasa sebesar 65,9\% Sedangkan faktor lain yang tidak diteliti dan turut mempengaruhi kinerja ditunjukkan oleh nilai $\mathrm{Py} \varepsilon=0.341$ atau sebesar $34,1 \%$.

\section{SARAN}

Dari kesimpulan yang bisa ditarik, maka dapat diberikan saran sebagai berikut :

1. Dengan melihat gambaran atas variabel yang diteliti ternyata masih dalam kategori cukup baik yang berarti belum pada kategori baik dan adanya pengaruh signifikan dari fungsi kepemimpinan, motivasi dan disiplin kerja terhadap kinerja, maka bagi perusahaan disarankan agar meningkatkan fungsi kepemimpinan, motivasi maupun disiplin kerja dengan memperbanyak pendikan dan pelatihan guna lebih meningkatkan kompetensi baik skill, pengetahuan maupun sikap karyawan. 
2. Dengan melihat pengaruh secara simultan dari fungsi kepemimpinan, motivasi dan disipin kerja terhadap kinerja ternyata baru sebesar 65,9\%, maka ternyata masih terdapat nilai pengaruh atas variabel lain sebesar $34,1 \%$. Untuk itu perlu dilakukan penelitian lanjutan atas variabel lain seperti misalnya budaya organisasi, komunikasi, pendidikan pelatihan dan sebagainya.

\section{DAFTAR PUSTAKA}

Ainsworth, Murray, Smith, Neville \& Millership, Anne, 2002. Managing Performance Managing People, Jakarta: PT. Bhuana Ilmu Populer, Kelompok Gramedia.

Arikunto, Suharsimi. 2003. Prosedur Penelitian Suatu Pendekatan Praktik. Jakarta: PT. Rineka Cipta

Bernadin, Russell, 1998. Human Resources Management, New York : McGraw-Hill.

Burke, David, Agustus 2009. Organisasi, Bertransformasi, Horizon Jurnal.

Burke, David, Januari 2009. Strategi Menuju Perusahaan yang Kompetitif, Horizon Jurnal.

Burke, David, Juli 2009. Corporate Strategy Scenario 2010-2014 With New Strategic Objective, Horizon jurnal.

Burke, David, November 2008. Faktor Perilaku Terhadap Sukses Transformasi, Horizon Jurnal

Dharma, Surya dan Yuanita Sunatrio, 2002. Human Resource Scorecard: Suatu Model Pengukuran Kinerja Sumber Daya Manusia, Yogyakarta: Penerbit Amara Books

Faustino Cardono Gomes, 2002. Manajemen Sumber Daya Manusia, Yogyakarta: PT. Andi.

Flippo, 1984. Manajemen Peronalia, Surabaya: Erlangga.

Fred, Luthan, 2006. Organiztion behavieor ( 10th Ed ). New Jersey : McGraw Hill

Gary Desler, 2006. A Framework for Human Resources Management, Fourth Edition Prentice Hall International.

Gaspersz,Vincent, 2007. Organizational Excellence: Model Strategik Menuju World Class Quality Company, Jakarta: P.T Gramedia Pustaka Utama.

Gibson, Ivancevich. 2009. Organisasi dan Manajemen Perilaku Struktur Proses. Jakarta: Penerbit

Gomes, Faustino Cardoso, 2003. Manajemen Sumber Daya Manusia. Yogyakarta: Andi Offset. 
http://images.deovera1979. multiplycontent.com

http://jurnal-sdm.blogspot.com/2009/05/disipiln-kerja-pegawai.html

http://pdf.hulifile.com/jurnal-manajemen-sdm-tentang-disiplin-kerja-terhadap-kinerjapegawai

Ivancevich, John M. 2001. Human Resource Management, Eight Edition, New York: McGraw Hill Companies.

John Suprianto, 1986. Konsep Dasar dan Pengertian Produktifitas serta Interpretasi Hasil Pengukurannya, Prisma No. 11.

Kenney, J and Reid, M, 1988. Training Initiatives, London : Institute Personnel Management, diterjemahkan Totok Budi Santoso, 2000, Penerbit Andi and Pearson Education Asia Pte. Ltd.

Kurniadi,Dede Hasan, 2002. Kemampuan Manajerial dalam Memotivasi dan Mendisiplinkan Karyawan Dikaitkan dengan Produktivitas Kerjanya di Dinas Pendidikan Nasional Provinsi Jawa Barat, Tesis, Bandung: UPI

Laporan Akuntabilitas Kinerja PT. Mitrametal Perkasa Karawang Tahun 2015

Laporan Akuntabilitas Kinerja PT. Mitrametal Perkasa Karawang Tahun 2016

Laporan Akuntabilitas Kinerja PT. Mitrametal Perkasa Karawang Tahun 2017

Luthan, Fred, 2002. Organizational Behavior, Seven Edition, McGraw - Hill. Book. Co.

Mangkunegara, A.A Anwar Prabu, 2002. Manajemen Sumber Daya Manusia, Bandung: Remaja Rosda Karya.

Mangkunegara, Anwar Prabu. 2006. Evaluasi Kinerja SDM. Bandung: Refika Aditama.

Mangkunegara, Anwar Prabu. 2006. Manajemen Sumber Daya Manusia Perusahaan. Bandung: Remaja Rosda Karya

Mathis, Robert L dan Jackson, John H., 2002. Manajemen Sumber Daya Manusia, Buku 2. Jakarta: Salemba Empat

Mulyana, Dedy. 2001. Metodologi Penelitian Kuantitatif. Bandung: Rosda.

Noe, Hollenbeck, Gerhart Wright, 1997. Human Resource Management, Gaining to Competitive Advantage, International Edition, McGraw-Hill, Inc., USA.

Noe, Hollenbeck, Gerhart Wrigth, 2006. Human Resources Management, Gaining A Competitive Advantage, McGraw - Hill.

Riduwan, 2008. Cara menggunakan dan memakai Analisis Jalur (Path Analysis), Bandung: ALFABETA

Ridwan, 2002. Skala Pengukuran Variabel-variabel Penelitian, Bandung: 2002 
Rivai, Veithzal, 2004. Kepemimpinan dan Perilaku Organisasi, Jakarta: PT. Raja Grafindo Persada

Rivai, Viethzal dan Basri, Ahmad Fawzi Moh, 2005. Perfomance Appraisal, Jakarta: PT Raja Grafindo Persada

Rivai, Viethzal. 2004. Kepemimpinan dan Perilaku Organisasi. Jakarta: PT. Raja Grafindo Persada.

Robbin, Stephen P., 1993. Organizational Behavior, New Jersey : Prentice Hall. International Sixth Edition.

Robbins, Stephen P., 2007. Organizational Behavior $12^{\text {th }}$ New Jersey : Prentice Hall.

Robert L. Mathis, John H. Jackson, 2004. Human Resources Management $10^{\text {th }}$.

Sedarmayanti, 2001. Sumber Daya Manusia dan Produktifitas Kerja, Bandung : Mandar Maju.

Siagian, Sondang P. 2002. Kiat Meningkatkan Produktivitas Kerja, Jakarta: PT. Rineka Cipta.

Simanjuntak, Payaman J., Prof., Dr., 2005. Manajemen dan Evaluasi Kinerja, Fakultas Ekonomi Universitas Indonesia.

Singarimbun, Masri, 1990. Metodologi Penelitian Survey, Jakarta: LP3ES.

Sudjana, Prof., Dr., M.A., M.Sc., 2000. Statistika, Edisi Lima, Bandung: PT. Tarsito

Sukmalana, Soelaiman. 2009. Manajemen Kinerja Membangun Mengembangkan Kinerja Sumber Daya Manusia dan Organisasi/Bisnis. Jakarta: PT. Intermedia Personalia Utama.

Suprayitno, Bambang, 2004. Pengaruh Diklat Struktural terhadap Peningkatan Kinerja Pegawai di Lingkungan Departemen Energi dan Sumberdaya Mineral, Tesis, Bandung: UPI

Widyantono,1997. Pengaruh Kondisi Tempat Kerja dan Motivasi Kerja Terhadap Prestasi Kerja Karyawan Dinas Pekerjaan Umum Kabupaten Kulon Progo Provinsi D.I. Yogyakarta, Tesis, Yogyakarta: UGM

Winardi, J., Prof, 2009. Teori Organisasi dan Pengorganisasian, Jakarta: P.T Raja Grafindo Persada.

www.2dix.com/pdf-2010/jurnal-kompetensi-pegawai-pdf.php 